\title{
URGENSI AKAD DALAM HUKUM EKONOMI ISLAM
}

\section{Ramli Semmawi}

\begin{abstract}
Abstrak
Manusia tidak pernah lepas dari kontrak (perjanjian/akad) dalam kehidupannya. Untuk melegalkan setiap hubungan maka akad senantiasa menjadi acuan dalam kehidupan. Misalkan, seorang laki-laki dan seorang perempuan terikat pernikahan hanya apabila telah dilaksanakan akad nikah. Dalam kegiatan perekonomian umat, lahirnya jual beli pasti dimulai dengan akad, demikian pula terjadinya sewa menyewa didahului oleh akad. Hal demikian menggambarkan bahwa akad sangat penting dalam kehidupan manusia.

Untuk memahami akad tersebut maka penulis melakukan telusuran pustaka yang membahas tentang landasan filosofis dalam perjanjian (akad) Islam. Kemudian dilakukan analisis dengan memberi contoh kasus sebagai bahan kajian.

Hasil studi yang dilakukan ditemukan bahwa ada tiga poin penting yang sepatutnya diperhatikan dalam akad. Pertama, penting dipahami bahwa asas-asas yang melahirkan akad tersebut merupakan acuan moral agama. Kedua, memahami syarat dan rukun dalam akad merupakan aspek penting kedua yang sepatutnya dipenuhi dalam akad. Ketiga, pemahaman yang lebih baik tentang asas, rukun dan syarat pada akad akan melahirkan para pihak yang bertanggung jawab dalam melaksanakan isi perjanjian kontrak yang dilahirkan dan senantiasa menjunjung tinggi nilai ajaran agama sebagai spirit di dalamnya.

Kata kunci: Akad, musyarakah, hukum Islam, ekonomi Islam.
\end{abstract}

* Dosen Jurusan Syariah STAIN Manado. 


\section{Pendahuluan}

Hukum Islam yang mengatur hubungan antarsesama manusia yang menyangkut ekonomi dan bisnis dikenal dengan istilah fikih muamalah. Fikih muamalah memuat norma dasar sebagai pedoman. Adapun operasionalisasinya secara terperinci diserahkan kepada umat manusia, sesuai dengan kebutuhan dan kemaslahatan mereka. De- ngan demikian, praktik muamalah dapat mengalami perubahan se- suai dengan perkembangan masyarakat.

Umumnya, aspek dan materi muamalah berkaitan dengan masalah akad (perjanjian, kontrak) atau transaksi. Secara etimologis, akad ber- arti perikatan, dan secara terminologis berarti ikatan antara dua pi- hak untuk menetapkan perbuatan hukum syara' tertentu yang ber- laku serta berakibat hukum bagi salah satu atau kedua belah pihak yang berakad. Menurut Wahbah az-Zuhaili, ahi fikih kontemporer dari Suriah, akad berarti pengikatan ijab dengan kabul sesuai dengan cara yang telah ditentukan oleh syara' dan mempunyai akibat hukum tertentu bagi pelakunya.

Menurut Tahir Azhary, hukum perjanjian Islam adalah merupakan seperangkat kaidah hukum yang bersumber dari al-Quran, Hadits, dan Ra'yu (Ijtihad) yang mengatur hubungan antara dua orang atau lebih mengenai suatu benda yang dihalalkan menjadi obyek suatu transaksi. Sementara Ahmad Azhar Basyir, memberikan definisi akad sebagai berikut, akad adalah suatu perikatan antara ijab dan kabul dengan cara yang dibenarkan syara' yang menetapkan adanya akibat-akibat hukum pada obyek. Ijab adalah pernyataan pihak pertama me- ngenai isi perikatan yang diinginkan, sedang kabul adalah pernyataan pihak kedua untuk menerimanya.

Akad dalam kehidupan umat manusia begitu penting karena ia

Fathurrahman Djamil. "Fikih Muamalah", dalam Taufik Abdullah (ed) Ensiklopedi Tematis Dunia Islam, Jilid III, (Jakarta: Ichtiar Baru van Hoeve, 2005), h. 133.

Ibid. hlm. 134.

Gemala Dewi. Hukum Perikatan Islam di Indonesia, (Jakarta: Kencana. 2005), h. 3.

Basyir, Ahmad Azhar. Asas-Asas Hukum Muamalat: Hukum Perdata Islam, (Yogyakarta: UII Press, 2000), h. 65. 
merupakan salah satu faktor menjadi halalnya sesuatu bagi mereka. Misalnya, untuk mempersatukan seorang laki-laki dan seorang perem- puan dalam suatu perkawinan, maka akad merupakan ikatan yang sah dan menjadi keharusan baginya. Hal lain juga terjadi dalam berba- gai interaksi kehidupan manusia. Jual beli, sewa menyewa dan lain se-againya merupakan contoh di mana terjadi kontrak (akad) atau perjanjian sebagai landasan hukumnya.

Pada kenyataannya, banyak pihak yang melakukan kontrak (perjanjian) yang masih belum memahami hak dan kewajiban yang mereka harus penuhi, sehingga walaupun menggunakan sistem perjanjian hukum Islam, tetapi nilai-nilai yang ada dalam konsep tersebut belumlah dijalankan sepenuhnya. Misalnya, dalam perjanjian akad dalam perbankan masih ditemukan bahwa hanya pihak bank yang memahami kontrak tersebut sementara pihak nasabah belum memahami betul apa yang menjadi hak dan kewajibannya dalam kontrak.

Ketika salah satu pihak tidak memiliki pemahaman yang sama da- lam kontrak, maka dimungkinkan adanya perlakuan yang tidak adil dalam kontrak tersebut. Dalam rangka memberi pemahaman bagi para pihak, maka penulis, memaparkan tulisan ini sebagai sumbangsih pemikiran dalam wacana hukum ekonomi Islam.

Berangkat dari asumsi tersebut di atas, yang menjadi fokus tulisan ini adalah: "Mengapa akad menjadi penting dalam sistem hukum ekonomi Islam?" Untuk menjawab pertanyaan tersebut, terlebih dahulu akan dipaparkan tentang asas-asas perjanjian dalam hukum Islam, selanjutnya menjelaskan tentang syarat dan rukun akad. Dan sebagai akhir dari pembahasan tulisan ini, dijelaskan tentang tanggung jawab para pihak dalam kontrak. Dengan demikian, diharapkan tulisan ini dapat memberi sumbangsih pemikiran bagi perkembangan hukum ekonomi Islam di Indonesia dan hukum kontrak Islam khususnya.

\section{Pembahasan}

\section{Asas-asas dalam Perjanjian Hukum Islam}

Asas berasal dari bahasa Arab asasun yang berarti dasar, basis, dan fondasi. Secara terminologi, asas adalah dasar atau sesuatu yang menjadi 
tumpuan berpikir atau berpendapat. Istilah lain yang memiliki arti sama dengan kata asas adalah prinsip, yaitu dasar atau kebenaran yang menjadi pokok dasar berpikir, bertindak, dan sebagainya. Moham- mad Daud Ali, mengartikan asas apabila dihubungkan dengan kata hukum adalah kebenaran yang dipergunakan sebagai tumpuan berpi- kir dan alasan pendapat, terutama, dalam penegakan dan pelaksanaan hukum.

Syamsul Anwar mengemukan delapan asas yang berkaitan dengan hukum perikatan Islam, yaitu asas Ibahah, asas kebebasan berakad, asas konsensualisme, asas janji itu mengikat, asas keseimbangan, asas kemaslahatan, asas amanah, dan asas keadilan. Adapun asas-asas itu adalah sebagai berikut:

a. Asas Ibahah (Mabda' al-Ibahah)

Asas ibahah adalah asas umum hukum Islam dalam bidang muamalah secara umum. Asas ini dirumuskan dalam adiqium "Pada asasnya segala sesuatu itu boleh dilakukan sampai ada dalil yang melarangnya." Asas ini merupakan kebalikan dari asas yang berlaku dalam masalah ibadah. Dalam hukum Islam, untuk tindakan-tindakan ibadah berlaku asas bahwa bentuk-bentuk ibadah yang sah adalah bentuk-bentuk yang disebutkan dalam dalil-dalil sya- riah. Orang tidak dapat membuat-buat bentuk baru ibadah yang ti- dak pernah ditentukan oleh Nabi Saw. Bentuk-bentuk baru ibadah yang dibuat tanpa pernah diajarkan oleh Nabi Saw itu disebut bid'ah dan tidak sah hukumnya.

b. Asas Kebebasan Berakad (Mabda' Hurriyyah at-Ta'aqud)

Menurut Faturrahman Djamil, bahwa Syariah Islam memberikan kebebasan kepada setiap orang yang melakukan akad sesuai dengan yang diinginkan, tetapi yang menentukan akibat hukumnya adalah

\footnotetext{
Departemen Pendidikan Nasional, Kamus Besar Bahasa Indonesia, Cet. II, Ed. III, (Jakarta: Balai Pustaka, 2002), h. 70.

Ibid., h. 896.

Mohammad Daud Ali. Hukum Islam: Pengantar Ilmu Hukum dan Tata Hukum Islam di Indonesia, Cet. VIII, (Jakarta: RajaGrafindo Persada, 2000), h. 114. Syamsul Anwar, Hukum Perjanjian Syariah: Studi tentang Teori Akad dalam Fikih Muamalat, (Jakarta: PT. RajaGrafindo Persada, 2007), h. 83-92.

Ibid., h. 84.
} 
ajaran agama. ${ }^{10}$ Mayoritas ulama fikih sepakat bahwa keridhaan (kerelaan) merupakan dasar berdirinya akad (kontrak). ${ }^{11} \mathrm{Hal}$ ini berdasarkan pada firman Allah: "Hai orang-orang yang beriman, janganlah kalian saling memakan (mengambil) harta sesamamu de- ngan jalan yang batil, kecuali dengan jalan perniagaan yang berlaku dengan sukarela di antaramu." 12

Ayat ini menjelaskan hukum Islam mengakui kebebasan berakad, yaitu suatu prinsip hukum yang menyatakan bahwa setiap orang dapat membuat akad jenis apa pun tanpa terikat kepada nama-nama yang telah ditentukan dalam undang-undang syariah dan memasukkan klausul apa saja ke dalam akad yang dibuatnya itu sesuai dengan kepentingannya sejauh tidak berakibat makan harta sesama dengan jalan batil. ${ }^{13}$ Adanya asas kebebasan berakad dalam Islam didasarkan kepada beberapa dalil antara lain adalah:

1. Firman Allah: "Wahai orang-orang beriman, penuhilah akad-akad (perjanjian-perjanjian)." 14

2. Sabda Nabi Saw: "Orang-orang Muslim itu senantiasa setia ke-pada syarat-syarat (janji-janji) mereka."15

3. Sabda Nabi Saw: "Barangsiapa menjual pohon korma yang sudah dikawinkan, maka buahnya adalah untuk penjual [tidak ikut di-jual], kecuali apabila pembeli mensyaratkan lain." 16

4. Kaidah hukum Islam: Pada asasnya akad itu adalah kesepakatan para pihak dan akibat hukumnya adalah apa yang mereka tetap- kan atas diri mereka melalui janji. "17

10 Faturrahman Djamil, "Hukum Perjanjian Syariah", dalam Kompilasi Hukum Perikatan oleh Mariam Darus Badzrulzaman et. al. Cet. I, (Bandung: Citra Aditya Bakti, 2001), h. 249.

11 Dimyauddin Djuwaini, Pengantar Fiqh Muamalah, Cet. I, (Yogyakarta: Pustaka Pelajar, 2008), h. 60.

12 QS. Surah an-Nisa'[4]: 29.

13 Anwar, Syamsul, op. cit., h. 84.

14 QS. Al-Maidah [5]: 1.

15 Al-Hakim, al-Mustadrak, II, Makktabah wa Matabi' an-Nasyr al-Hadistsah, Riyad, t.t. hlm. 49. Hadis ini diriwayatkan oleh Al-Hakim dari Sahabat Abu Hurairah, dikutip dari Syamsul Anwar, op. cit., h. 85.

16 Al-Bukhari, Shahih al-Bukhari, III, Dar al-Fikr, tt.p., 1994, Hadis No. 2204. 17 Asjmuni A. Rahman, Qaidah-Qaidah Fiqih, (Jakarta: Bulan Bintang, 1975), h. 
Cara menyimpulkan kebebasan berakad dari ayat yang dikutip pada angka 1) adalah bahwa menurut kaidah usul fikih (metodologi penemuan hukum Islam), perintah dalam ayat ini menunjukkan wajib. Artinya memenuhi akad itu hukumnya wajib. Dalam ayat ini akad disebutkan dalam bentuk jamak yang diberi kata sandang "al" (al-'uqud) menunjukkan kaidah umum. ${ }^{18}$ Hadits pada angka 2) menunjukkan bahwa syarat-syarat atau janji-janji apa saja da- pat dibuat dan wajib dipenuhi. Terhadap Hadits ini al-Kasani (w.587/1190) memberi penjelasan, Zahir Hadits ini menyatakan wajibnya memenuhi setiap perjanjian selain yang dikecualikan oleh suatu dalil, karena Hadits ini menuntut setiap orang untuk setia kepada janjinya, dan kesetiaan kepada janji itu adalah dengan memenuhi janji tersebut. Asasnya ialah bahwa setiap tindakan hukum seseorang terjadi menurut yang ia kehendaki apabila ia adalah orang yang cakap untuk melakukan tindakan tersebut, obyeknya dapat menerima tindakan dimaksud, dan orang bersangkutan mempunyai kewenangan dalam tindakan itu."19

c. Asas Konsensualisme (Mabda' ar-Radha'iyyah)

Asas konsensualisme menyatakan bahwa untuk terciptanya suatu perjanjian cukup dengan tercapainya kata sepakat antara para pi-

hak tanpa perlu dipenuhinya formalitas-formalitas tertentu. ${ }^{20}$ Da- lam Hukum Islam pada umumnya perjanjian-perjanjian itu bersi- fat konsensual.

Para ahli hukum Islam biasanya menyimpulkan asas konsensualisme dari dalil-dalil hukum berikut:

1. Firman Allah, "Wahai orang-orang beriman, janganlah kamu makan harta sesamamu dengan jalan batil, kecuali (jika makan harta sesama itu dilakukan) dengan cara tukar-menukar berdasarkan perizinan timbal balik (kata sepakat) di antara kamu. "21

44, dikutip dari Syamsul Anwar, op. cit., h. 85.

18 Muhammad Abu Zahrah, Ushul al-Fiqh, (t.p.: Dar al-Fikr al-'Arabi, t.t.), hlm. 157, dikutip dari Syamsul Anwar,ibid., hlm. 85.

19 Al-Kasani, Bada' $i$ ' ash-Shana'i' fi Tartib asy-Syaraki',V, Matba'ah alJamaliyyah, Mesir, 1910, hlm. 259, dikutip dari, Syamsul Anwar, ibid.

20 Anwar, Syamsul, ibid., hlm. 87.

21 QS. Surah an-Nisa'[4]: 29. 
2. Firman Allah: "Kemudian jika mereka menyerahkan kepadamu sebagian dari mas kawin itu atas dasar senang hati (perizinan), maka makanlah (ambillah) pemberian itu sebagai suatu yang se- dap lagi baik akibatnya."22

3. Sabda Nabi Saw: Sesungguhnya jual-beli itu berdasarkan kata se- pakat (Hadits riwayat Ibnu Hibban dan Ibnu Majah). ${ }^{23}$

4. Kaidah hukum Islam, Pada asasnya perjanjian (akad) itu adalah kesepakatan para pihak dan akibat hukumnya adalah apa yang mereka tetapkan melalui janji. ${ }^{24}$

Kutipan ayat pada angka 1) di atas menunjukkan antara lain bahwa setiap pertukaran secara timbal balik diperbolehkan dan sah selama didasarkan atas kesepakatan. Ayat pada angka 2) menunjukkan bahwa suatu pemberian adalah sah apabila didasarkan kepada perizinan (rela hati) si pemberi. Hadits Nabi Saw pada angka 3) dengan jelas menunjukkan bahwa akad jual-beli didasarkan kepada perizinan timbal-balik (kata sepakat). Kaidah hukum pada angka 4) secara tegas menyatakan bahwa perjanjian itu pada asasnya adalah kesepakatan para pihak, sehingga bila telah tercapai kata sepakat para pihak, maka terciptalah suatu perjanjian. ${ }^{25}$

d. Asas Janji itu Mengikat

Perintah agar memenuhi perjanjian, banyak terdapat dalam alQuran dan Hadits. Kaidah usul fikih, "perintah itu pada asasnya menunjukkan wajib." 26 Ini berarti bahwa janji itu mengikat dan wajib dipenuhi. Adapun ayat dan Hadits yang dimaksud adalah:

1. Firman Allah: “...dan penuhilah janji, sesungguhnya janji itu akan dimintakan pertanggunjawabannya." 27

22 QS. Surah an-Nisa'[4]: 4.

23 Ibn Hibban, Shahih Ibn Hibban, Mu'assasah ar-Raisalah, Beirut, 1414/1993, XI, 340, Hadis, no. 4967; dan Ibn Majah, Sunan Ibn Majah, Dar al-Fikr, Beirut, t.t., II, 737 Hadis no. 2185, dikutip dari Syamsul Anwar, op. cit., hlm. 88

24 Anwar, Syamsul, ibid.

25 Ibid., hlm. 88-89.

26 Ibid., hlm. 89.

27 QS. Surah Al Israa' [17]: 34. 


\section{Asar dari Ibn Mas'ud, Janji itu adalah utang. "28}

e. Asas Keseimbangan (Mabda' at-Tawazun fi al-Mu'awadhah)

Secara faktual jarang terjadi keseimbangan antara para pihak dalam bertransaksi, namun hukum perjanjian Islam tetap menekankan perlunya keseimbangan itu, baik keseimbangan antara apa yang diberikan dan apa yang diterima maupun keseimbangan dalam memikul risiko. Asas keseimbangan dalam transaksi (antara apa yang diterima dan apa yang diberikan) tercermin pada dibatalkannya suatu akad yang mengalami ketidakseimbangan prestasi yang mencolok. Asas keseimbangan dalam memikul risiko tercermin dalam larangan terhadap transaksi riba, di mana dalam konsep riba hanya debitur yang memikul segala risiko atas kerugian usaha, sementara kreditor bebas sama sekali dan harus mendapat persentase tertentu sekalipun pada saat dananya mengalami kembalian negatif. ${ }^{29}$

\section{f. Asas Kemaslahatan (Tidak Memberatkan)}

Asas kemaslahatan dimaksudkan bahwa akad yang dibuat oleh para pihak bertujuan untuk mewujudkan kemaslahatan bagi mereka dan tidak boleh menimbulkan kerugian (mudharat) atau keadaan memberatkan (masyaqqah). Apabila dalam pelaksanaan akad terjadi suatu perubahan keadaan yang tidak dapat diketahui sebelumnya serta membawa kerugian yang fatal bagi pihak bersangkutan se- hingga memberatkannya, maka kewajibannya dapat diubah dan disesuaikan kepada batas yang masuk akal. ${ }^{30}$

g. Asas Amanah

Asas amanah dimaksudkan bahwa masing-masing pihak haruslah beritikad baik dalam bertransaksi dengan pihak lainnya dan tidak dibenarkan salah satu pihak mengeksploitasi ketidaktahuan mitranya. Sekarang ini, banyak sekali obyek transaksi yang dihasilkan oleh satu pihak melalui suatu keahlian yang amat spesialis dan

28 Asar ini diriwayatkan secara maukuf oleh al-Bukhari dalam al-Adab al-Mufrad. Sedangkan at-Tabarani dalam al-Mu'jam al-Ausat dan al-Mu'jam ash-Shagir meriwayatkannya secara marfuk dari Nabi Saw melalui Sahabat 'Ali. Dikutip dari Syamsul Anwar, op. cit., h. 89.

29 Ibid., h. 90.

30 Ibid. 
profesionalisme yang tinggi sehingga ketika ditransaksikan, pihak lain yang menjadi mitra transaksi tidak banyak mengetahui selukbeluknya. Oleh karena itu, dalam kaitan ini dalam hukum perjanjian Islam dituntut adanya sikap amanah para pihak yang menguasainya untuk memberi informasi yang sejujurnya kepada pihak lain yang tidak banyak mengetahuinya. ${ }^{31}$

Salah satu pihak hanya bergantung kepada informasi jujur dari pihak lainnya untuk mengambil keputusan untuk menutup perjan- jian bersangkutan. Perjanjian tersebut dalam hukum Islam, dikenal dengan istilah perjanjian amanah.

h. Asas Keadilan

Asas keadilan sebagaimana dijelaskan dalam QS al-Hadid [57]: 25 disebutkan, bahwa Allah berfirman, "Sesungguhnya Kami telah mengutus Rasul-Rasul Kami dengan Membawa bukti-bukti yang nyata dan telah Kami turunkan bersama mereka Al-Kitab dan Neraca (keadilan) supaya manusia melaksanakan keadilan."32 Adil merupakan salah satu sifat Allah SWT yang sering disebutkan dalam alQuran. Bersikap adil kerap ditekankan oleh Allah SWT kepada manusia dalam melakukan perbuatan, karena adil menjadikan manusia lebih dekat kepada takwa. Lebih lanjut, dalam Surah al-A'raaf [7]: 29, disebutkan bahwa, "Katakanlah: "Tuhanmu menyu-

ruh supaya berlaku adil." 33 Serta dalam Surah Al-Maaidah [5]: 8, disebutkan berikut ini:

Wahai orang-orang yang beriman, hendaklah kamu jadi orangorang yang selalu menegakkan (kebenaran) karena Allah, menjadi saksi dengan adil. Dan janganlah sekali-kali kebencianmu terhadap sesuatu kaum, mendorong kamu untuk berlaku tidak adil. Berlaku adillah, karena adil itu lebih dekat kepada takwa. Dan bertakwalah kepada Allah, sesungguhnya Allah Maha Mengetahui apa yang kamu kerjakan."34

31 Ibid., h. 91.

32 QS. Al-Hadid [57]: 25.

33 QS. Al-A'raaf [7]: 29.

34 QS. Al-Maidah [5]: 8. 
Keadilan adalah tujuan yang hendak diwujudkan oleh semua hukum. Keadilan merupakan sendi setiap perjanjian yang dibuat oleh para pihak. Seringkali di zaman modern akad ditutup oleh salah satu pihak dengan pihak lain tanpa ia memiliki kesempatan untuk ber- musyawarah mengenai klausul akad tersebut, karena klausul akad itu telah dibakukan oleh pihak lain. Tidak mustahil bahwa dalam pelaksanaannya akan timbul kerugian kepada pihak yang menerima syarat baku itu karena didorong kebutuhan. Hal mana dalam hukum Islam kontemporer telah diterima suatu asas bahwa demi keadilan syarat baku itu dapat diubah oleh pengadilan apabila memang ada alasan untuk itu. ${ }^{35}$

\section{Syarat dan Rukun Akad (Perjanjian)}

Rukun dan syarat merupakan hal yang harus terpenuhi dalam suatu perjanjian. Secara bahasa, rukun adalah "yang harus dipenuhi untuk sahnya suatu pekerjaan,"36 sedangkan syarat adalah "ketentuan (peraturan, petunjuk) yang harus diindahkan dan dilakukan." ${ }^{37}$ Rukun dan syarat, dalam syariah, sama-sama menentukan sah atau tidaknya suatu transaksi. Sedangkan dalam Ensiklopedi Hukum Islam, didefinisikan, rukun adalah "suatu unsur yang yang merupakan bagian tak terpisahkan dari suatu perbuatan atau lembaga yang menentukan sah atau tidaknya perbuatan tersebut dan ada atau tidak adanya sesuatu itu." 38 Definisi syarat adalah "sesuatu yang tergantung padanya keberadaan hukum syar'i dan ia berada di luar hukum itu sendiri." 39

a. Rukun Perjanjian

Akad memiliki tiga rukun, yaitu adanya dua orang atau lebih yang melakukan akad, obyek akad, dan lafal (shighat) akad.

1. Dua Pihak atau lebih yang Melakukan Akad

Dua orang atau lebih yang melakukan akad ini adalah dua orang

35 Anwar, Syamsul, op. cit., h. 92.

36 Departemen Pendidikan Nasional, op. cit., h. 966.

37 Ibid., h. 1114.

38 Abdul Azis Dahlan (ed), Ensiklopedi Hukum Islam, Jilid 5, Cet. I, (Jakarta:

Ichtiar Baru van Hoeve, 1996), h. 1510.

39 Ibid., h. 1691. 
atau lebih yang secara langsung terlibat akad. Kedua belah pihak dipersyaratkan harus memiliki kelayakan untuk melakukan akad sehingga perjanjian atau akad tersebut dianggap sah. Kelayakan terwujud dengan beberapa hal berikut:

Pertama, kemampuan membedakan yang baik dan yang buruk. Yakni apabila pihak-pihak tersebut sudah berakal lagi baligh dan tidak dalam keadaan tercekal. Orang yang tercekal karena dianggap idiot atau bangkrut total, tidak sah melakukan perjan- jian.

Kedua, bebas memilih. Tidak sah akad yang dilakukan orang di bawah paksaan, kalau paksaan itu terbukti. Misalnya orang ber- utang dan butuh pengalihan utangnya, atau orang yang bang- krut, lalu terpaksa menjual barangnya untuk menutupi utang- nya.

Ketiga, akad itu dapat dianggap berlaku (jadi total) bial tidak memiliki pengandaian yang disebut khiyar (hak pilih). Seperti khiyar syarath (hak pilih menetapkan persyaratan), khiyar arru'yah (hak pilih dalam melihat) dan sejenisnya. ${ }^{40}$

\section{Obyek Akad (Transaksi)}

Yakni benda yang menjadi obyek akad, seperti barang yang di- jual dalam akad jual-beli, atau sesuatu yang disewakan dalam akad sewa, yang dihibahkan dalam akad hibah, yang digadai dalam akad rahn dan lain-lain. ${ }^{41}$

\section{Lafal (shighat) Akad}

Ijab kabul merupakan ungkapan yang menunjukkan kerelaan/ kesepakatan dua pihak yang melakukan kontrak/akad. Menurut Hanafiyah, ijab adalah ungkapan yang pertama kali dilontarkan oleh salah satu dari pihak yang akan melakukan akad. Di mana ia menunjukkan maksud/kehendak dengan penuh kerelaan, baik datangnya dari pihak penjual atau pembeli dalam jual-beli.

40 Abdullah Al-Mushlih dan Shalah Ash-Shawi, Ma La Yasa' at-Tajira Jahluhu, terjemahan oleh Abu Umar Basyir, Fikih Ekonomi Keuangan Islam, Cet. II, (Jakarta: Darul Haq, 2008), h. 27.

41 Sofiniyah Ghufron (editor), Cara Mudah Memahami Akad-akad Syariah, Cet. I, (Jakarta: Renaisan, 2005), h. 14. 
Kabul adalah sebaliknya. ${ }^{42}$

Ijab kabul dapat diwujudkan dalam pelbagai bentuk (shighat) yang dapat menunjukkan kehendak dan kesepakatan. Bisa dengan ucapan, tindakan, isyarat, atau korespondensi. Ucapan da- pat diungkapkan dalam pelbagai macam bentuk, yang terpen- ting dapat merepresentasikan maksud dan tujuannya.

4. Syamsul Anwar menambahkan "tujuan akad" merupakan salah satu rukun yang harus ada dalam akad. Tujuan akad, yang merupakan rukun keempat menurut beberapa ahli hukum Islam kontemporer, dibedakan dengan obyek akad, yang merupakan rukun ketiga akad. Obyek akad adalah suatu yang karena itu ber- laku akibat hukum pokok yang menjadi maksud para pihak. De- ngan kata lain, obyek akad merupakan tempat terjadinya akibat hukum, sedangkan tujuan akad adalah maksud para pihak yang bila terealisasi timbul akibat hukum pada obyek tersebut. ${ }^{43}$

b. Syarat Perjanjian

Menurut mazhab Hanafi, syarat yang ada dalam akad/perjanjian, dapat dikategorikan menjadi tiga bagian, yakni syarat shahih, fasid (rusak), dan syarat bathil.

1. Syarat shahih adalah syarat yang sesuai dengan substansi akad, dibenarkan oleh syara' atau sesuai dengan 'urf (kebiasaan) masya- rakat.

2. Syarat fasid adalah syarat yang tidak sesuai dengan salah satu kriteria yang ada dalam syarat shahih. Artinya, ia tidak sesuai de- ngan substansi akad atau mendukungnya, tidak ada nash atau tidak sesuai dengan 'urf (kebiasaan) masyarakat, dan syarat itu memberikan manfaat bagi salah satu pihak.

3. Syarat batil adalah syarat yang tidak memenuhi kriteria syarat shahih, dan tidak memberikan nilai manfaat bagi salah satu pi- hak atau lainnya. Akan tetapi, malah menimbulkan dampak negatif bagi salah satu pihak. ${ }^{44}$

42 Dimyauddin Djuwaini, op. cit., h. 51.

43 Syamsul Anwar, op. cit., h. 219-220.

44 Wahbah Zuhaili, Al-Fiqh al-Islami wa Adillatuhu, Jilid IV, (Damaskus: Daar al

Fikr, 1989), h. 203-205, dikutip dari Dimyauddin Djuwaini, op. cit., h. 63-64. 
Sedangkan Sofiniyah Ghufron dalam buku Cara Mudah Memahami Akad-Akad Syariah menjelaskan bahwa ada beberapa syarat yang harus terdapat dalam akad, tetapi bisa dibagi menjadi dua macam:

Pertama, syarat umum, yaitu syarat-syarat yang wajib sempurna wujudnya dalam segala macam akad.

Kedua, syarat khusus, yaitu syarat-syarat yang diisyaratkan wujudnya dalam sebagian akad, tidak dalam sebagian yang lain. Syarat-syarat ini biasa juga disebut syarat tambahan (syarat idhafiyah) yang harus ada di samping syarat-syarat umum, seperti adanya saksi untuk terjadinya nikah, tidak boleh adanya ta'liq dalam aqad mauwadha dan aqad tamlik, seperti jual-beli dan hibah. Ini merupakan syarat-syarat idhafiyah. ${ }^{45}$

\section{Tanggung Jawab Pihak-pihak dalam Akad (Perjanjian)}

Dalam berbagai hukum perjanjian, apabila suatu akad (perjanjian) telah memenuhi semua syarat-syaratnya - dan menurut hukum perjanjian Islam apabila telah memenuhi rukun dan syarat-syaratnya-perjanjian tersebut mengikat dan wajib dipenuhi serta berlaku sebagai hukum. Dengan kata lain perjanjian tersebut menimbulkan akibat hukum yang wajid dipenuhi oleh pihak-pihak terkait.

Dalam Pasal 1338 (1) KUH Perdata ditegaskan, "Semua perjanjian yang dibuat secara sah berlaku sebagai undang-undang bagi merkea yang membuatnya." Sebagai kelanjutan dari asas mengikatnya perjanjian dan wajibnya para pihak memenuhi perikatan-perikatan yang timbul dari perjanjian tersebut, maka salah satu pihak tidak dapat menarik kembali perjanjiannya "selain dengan sepakat kedua belah pihak atau karena alasan-alasan yang oleh undang-undang dinyatakan cukup untuk itu" (Pasal 1338 ayat (2)).

Dalam hukum perjanjian Islam, seperti halnya dalam hukum lainnya, pada asasnya, tanggung jawab para pihak akibat adanya suatu akad (perjanjian) hanya berlaku terhadap para pihak yang membuatnya dan tidak berlaku terhadap pihak lain di luar mereka. Hal ini ditegaskan dalam kitab Mursyid al-Hairan: Pasal 306 (1):

45 Sofiniyah Ghufron (editor), op. cit., h. 18-19. 
Akibat-akibat hukum akad hanya berlaku terhadap para pihak yang membuatnya, dan tidak berlaku terhadap pihak lain selain mereka. Pasal 278: Orang balig dan berakal sehat serta tidak berada di bawah pengampuan dapat membuat akad apa pun secara sendiri maupun mewakilkannya kepada orang lain; barang siapa membuat akad secara sendiri dan untuk dirinya sendiri, maka dialah, dan bukan orang lain, yang terikat oleh hak-hak dan akibat-akibat hukum yan timbul dari akadnya. ${ }^{46}$

Berdasarkan pada pengertian akad/perjanjian, rukun dan syarat sahnya perjanjian, asas-asas hukum yang mendasarinya, maka dalam perjanjian menurut hukum Islam harus memperhatikan hal-hal berikut:

a. Dari segi subyek atau pihak-pihak yang akan mengadakan kontrak akad/perjanjian.

Subyek hukum yang mengadakan perjanjian harus sudah cakap melakukan perbuatan hukum, terdapat identitas para pihak dan kedudukan masing-masing dalam perjanjian secara jelas, dan perlu adanya kejelasan terhadap tempat dan saat perjanjian dibuat.

b. Dari segi tujuan dan obyek akad/perjanjian.

Sebuah perjanjian, di dalam Islam, harus disebutkan secara jelas tujuan dari dibuatnya perjanjian tersebut. Hal ini dimaksdukan jangan sampai membuat sebuah perjanjian dengan obyek yang ber- tentangan dengan ketentuan hukum Islam atau 'urf (kebiasaan/adat) yang sejalan dengan ajaran Islam. Meskipun dalam perjanjian Islam dianut asas kebebasan berkontrak sebagai asas yang fundamental dalam hukum perjanjian.

c. Perlu adanya kesepakatan dalam hal yang berkaitan dengan waktu perjanjian, jumlah biaya, mekanisme kerja, jaminan, penyelesaian sengketa, dan obyek yang diperjanjikan dan cara-cara pelaksanaan- nya.

d. Perlu adanya persamaan, kesetaraan, kesederajatan, dan keadilan di antara para pihak dalam menentukan hak dan kewajiban di anta- ranya, serta dalam hal penyelesaian permasalahlan terkait dengan adanya wanprestasi dari salah satu pihak.

46 Lihat Syamsul Anwar, op. cit., h. 264-265. 
e. Pemilihan hukum dan forum dalam penyelesaian (Choice of Law and Choice of Forum), harus dicantumkan dalm perjanjian, misalnya dengan mencantumkan klausul "bahwa dalam hal terjadi sengketa di kemudian hari, para pihak sepakat untuk menyelesaikannya de- ngan dasar hukum Islam di Badan Arbitrase Syariah Nasional yang wilayah hukumnya meliputi tempat dibuatnya perjanjian ini." 47

Hal-hal di atas perlu dimasukkan ke dalam sebuah naskah perjanjian dengan tidak menutup kemungkinan bagi para pihak memuat hal-hal yang dianggap penting, karena dalam pembuatan suatu perjanjian haruslah rigid dan harus dihindarkan adanya katakata yang bermakna ganda (multi interpretable). ${ }^{48}$ Sehingga, dapat mengurangi peluang ter- jadinya sengketa di kemudian hari.

Sebagai ilustrasi pentingnya akad dalam setiap transaksi yang selan- jutnya melahirkan tanggung jawab para pihak, maka akan diuraikan sedikit tentang salah satu model pembiayaan yang sering digunakan sebagai instrumen dalam sistem ekonomi Islam. Adapun model yang dimaksud adalah musyarakah.

Musyarakah (kemitraan) adalah salah satu dasar dari konsep Profit and Loss Sharing dalam literatur fikih. Definisi yang lain adalah kerja sama antara dua pihak atau lebih untuk suatu usaha tertentu di mana masing-masing pihak memberikan kontribusi dana (atau kom- petensi, expertise) dengan kesepakatan bahka keuntungan dan risiko akan ditanggung bersama sesuai dengan kesepakatan. ${ }^{49}$ Menurut Frank E. Vogel, kontrak musyarakah adalah keterlibatan dua pihak atau lebih dalam sebuah proyek yang masing-masing memberikan kontribusi modal dan manajemen. Proses pengambilan keputusan untuk pembagian dana dilakukan bersama-sama, biasanya sebanding dengan nilai relatif investasinya. ${ }^{50}$ Al-Quran menggunakan akar kata

47 Faturrahman Djamil, "Hukum Perjanjian Syariah," loc. cit., h. 260-261.

48 Abdul Ghofur Anshori, Perbankan Syariah di Indonesia, Cet. I, (Yogyakarta:

Gadjah Mada University Press, 2007), h. 63.

49 Dimyauddin Djuwaini, loc. cit. h. 207.

50 Frank E. Vogel dan Samuel L. Hayes, Islamic Law and Finance: Religion, Risk, and Return, terjemahan oleh M. Sobirin Asnawi, Siwi Purwandari dan Waluyati Handayani, Hukum Keuangan Islam: Konsep, Teori dan Praktik, Cet.

I, (Bandung: Nusamedia, 2007), h. 235. 
istilah musyarakah, yaitu $s y-r-k$, sebanyak $170 \mathrm{kali},{ }^{51}$ walau tak satu pun dari ayat ini yang menggunakan istilah musyarakah persis dengan arti kemitraan dalam suatu kongsi bisnis. Namun demikian, berdasarkan sejumlah ayat al-Quran, khususnya Surah An-Nisa'[4]: 12 dan Surat Shaad [38]: 24, maupun berdasarkan sejumlah riwayat yang dinisbatkan kepada Nabi dan para Sahabatnya, para fuqaha membenarkan keabsahan musyarakah dalam kongsi bisnis. ${ }^{52}$

Terjadinya kontrak dalam musyarakah juga melahirkan tanggung jawab bagi para pihak dalam transaksi terebut. Pembagian laba dan rugi merupakan salah satu aspek yang harus menjadi bagian tanggung jawab bagi para pihak. Pembagian laba antar mitra harus berupa persentase,- bukan suatu jumlah tertentu. Menurut kalangan mazhab Hanafi dan Hanbali, persentase tersebut harus ditentukan secara jelas dalam kontrak. Menentukan suatu jumlah tetap bagi seorang mitra tidak diperbolehkan lantaran total laba yang akan diperoleh barangkali tidak akan melebihi jumlah yang telah ditetapkan, dalam kasus seperti itu mitra lainnya bisa tidak memperoleh bagian laba tersebut. ${ }^{53}$ Bagi kalangan mazhab Syafii, tidak ada keperluan untuk menetapkan bagian laba dalam kontrak, sebab mereka tidak memperoleh adanya perbedaan antara rasio saham dalam modal dengan rasio laba. Menurut fakih mazhab Syafii, Imam Nawawi (w.676/1277), proposal laba dan rugi harus sama dengan proposal modal yang diberikan, baik tenaga yang disediakan oleh mitra setara ataupun tidak. ${ }^{54}$

Sementara kalangan mazhab Syafii tidak mengizinkan perbedaan rasio pembagian laba dengan rasio kontribusi modal, terdapat fleksibilitas yang berarti dalam menetapkan rasio itu menurut mazhab Hanafi dan Hanbali. Para mitra dapat berbagi laba secara setara atau pun tidak. Seorang mitra menyumbangkan sepertiga dari modal mu-

51 Abdullah Saeed, Islamic Banking and Interest: A Study of Riba' and Its Contem- porary Interpretation, terjemahan oleh, Arif Maftuhin, Menyoal Bank Syariah: Kritik atas Interpretasi Bunga Bank Kaum Neo-Revivalis, Cet. I, (Jakarta: Para- madina, 2006), h. 88.

52 Ibn Qudamah, Al-Mugni, V, (Riyad: Maktabat al-Riyad al-Haditha, 1981), h. 3, dikutip dari Saeed, ibid.

53 Ibn Qudamah, al-Mughni, V, hlm. 38; Kashani, Bada'i al-Sina'i,VI, h. 59 dikutip dari Saeed, ibid., h. 92.

54 Nawawi, minhaj, II, h. 215, dikutip dari Saeed, ibid. 
syarakah, misalnya, dapat memperoleh separoh atau lebih dari laba. Menurut fakih mazhab Hanafi, Kasyani (w. 587/1191), tidaklah harus bahwa di dalam 'inan (salah satu jenis musyarakah), laba harus dibagi setara antar para mitra. Itu sebabnya, diperbolehkan untuk membagai laba secara setara ataupun tidak. Prinsipnya, si mitra ber- hak mendapat laba baik karena pemberian modal berupa uang atau tenaga kerja, atau berupa tanggung jawab. ${ }^{55}$

Tidak ada fleksibilitas yang muncul dalam musyarakah menyangkut pembagian rugi vis a vis rasio kontribusi modal menurut keempat mazhab fikih Sunni, ${ }^{56}$ seperti yang dicerminkan dalam ungkapan-hukum, "pembagian rugi harus persis sama dengan rasio kontribusi modal.",57 Menurut Jaziri, "Jika salah satu mitra mententukan bahwa mitra yang lain harus menanggung risiko melebihi rasio kontribusi modal, maka kontrak ini batal dan tak berlaku." 58 Prinsip berikut menurut riwayat dinyatakan oleh khalifah keempat, Ali bin Abi Thalib (w. 40/660), "Laba harus dibagi sebagaimana yang disepakati di dalam kontrak, sementara kerugian harus dibagi menurut kontribusi modal." ${ }^{59}$ Syekh Ali al-Khafif menulis, "Kerugian selalu akan dibagi sesuai ukuran ter- hadap modal yang sebenarnya. Semua Imam sepakat akan hal ini meskipun mereka berasal dari kelompok berbeda. Jika ada ketentuan yang dipertentangkan dalam prinsip ini maka akan dianggap batal, tidak diberlakukan dan tidak akan dilaksanakan." 60

Contoh yang dikemukakan di atas dikemukakan sebagai argumentasi bahwa demikian penting akad dalam kehidupan umat manusia. Sehingga penting kiranya ada pemahaman komprehensif tentang akad (perjanjian) tersebut. Uraian itu juga ingin menggambarkan bahwa Islam telah mengatur demikian rupa tentang bagaimana seorang Muslim menjalani hidup dengan keteraturan dan disiplin sebagai salah

55 Kasyani, Badai' i' al-Shana 'i', VI, h. 62, dikutip dari Saeed, ibid.

56 Qudamah, Al-Mughni, V, h. 37, dikutip dari Saeed, ibid.

57 Sabiq, Fiqh Sunnah, III, h. 357, dikutip dari Saeed, ibid.

58 Jaziri, fiqh, III, h. 77, dikutip dari Saeed, ibid.

59 Syaukani, Nail al-Authar, V, h. 266, dikutip dari Saeed, ibid.

60 Syekh Ali al-Khafif, al-Syarikat fi al-Fiqh al-Islam, (Kairo: t.t., t.th.), h. 55, dikutip dari Nejatullah Siddiqi. Partnership and Profit Sharing in Islamic Law, terjemahan oleh, Fakhriyah Mumtihani, Kemitraan Usaha dan Bagi Hasil dalam Hukum Islam, Cet. I, (Yogyakarta: Dana Bhakti Wakaf, 1996), h. 15. 
satu aspek penghambaannya kepada sang Khalik.

\section{Penutup}

Sebagai penutup dari kajian ini, penulis menyimpulkan beberapa hal yang dianggap penting untuk dipahami sebagai berikut:

Pertama, akad dalam Islam didasari oleh nilai-nilai ajaran agama yang universal. Misalnya, keadilan, kesamaan kedudukan dalam kontrak, kebebasan dalam kontrak, dan lain-lain. Memahami asas-asas tersebut menjadi landasan filosofis dalam melaksanakan akad. Islam mengajarkan pelbagai nilai yang senantiasa harus dijadikan acuan dalam kehidupan. Kebebasan yang bertanggung jawab akan melahirkan sikap diri yang arif. Keadilan dalam diri menciptakan pribadi yang senantiasa mencintai sesama dan tidak aniayah. Nilai-nilai tersebutlah yang sepatutnya menjiwai setiap kontrak dalam Islam.

Kedua, rukun dan syarat yang sah dalam membuat kontrak merupakan sesuatu yang harus dipenuhi dalam rangka menciptakan kontrak (akad) yang sah dalam terminologi hukum Islam. Terpenuhinya rukun dan syarat dalam akad merupakan suatu hal yang mesti dijadikan acuan dalam setiap kontrak, karena hal itu merupakan pertanda sahnya suatu akad yang dilakukan. Adanya para pihak yang jelas, sighat yang benar, tujuan yang sahih dan tidak melanggar ajaran agama merupakan hal penting yang patut diketahui oleh para pihak.

Ketiga, tanggung jawab para pihak akan jelas apabila mereka memahami secara baik tentang asas-asas apa saja yang mendasari setiap kontrak dalam hukum ekonomi Islam. Dan demikian pula pada pemahaman yang baik akan rukun dan syarat sah dalam setiap perjanjian. Sehingga dalam setiap akad yang dibuat tidak keluar dari spirit ajaran agama Islam dan dengan demikian Islam sebagai ajaran moral, akhlak dan hukum tercipta dalam kehidupan umat. Para pihak yang melaksanakan tanggung jawab secara adil akan menciptakan kehi- dupan yang harmonis dan menciptakan rasa senang dan tenang bagi para pihak yang melaksanakan kontrak tersebut. Pelaksanaan tang- gung jawab secara baik merupakan bagian dari pelaksanaan ajaran agama dan penghargaan akan kemanusiaan. 


\section{Daftar Pustaka}

Al-Bukhari, 1994, Shahih al-Bukhari, Cet. III, (t.t.: Dar al-Fikr).

Al-Hakim, t.th. al-Mustadrak, II, (Riyad: Makktabah wa Matabi' anNasyr al-Hadistsah).

Ali, Mohammad Daud, 2000, Hukum Islam: Pengantar Ilmu Hukum dan Tata Hukum Islam di Indonesia, (Jakarta: RajaGrafindo Persada).

Al-Kasani, 1910, Bada 'i' ash-Shana 'i' fi Tartib asy-Syaraki', Cet. V, (Mesir: Matba'ah al-Jamaliyyah).

Al-Khafif, Syekh Ali, t.th., Al-Syarikat fi al-Fiqh al-Islam, (Kairo: t.p.).

Al-Mushlih, Abdullah dan Shalah Ash-Shawi, 2008, Ma La Yasa' atTajira Jahluhu, terjemahan oleh Abu Umar Basyir, Fikih Ekonomi Keuangan Islam, (Jakarta: Darul Haq).

Anshori, Abdul Ghofur, 2007, Perbankan Syariah di Indonesia, (Yogya- karta: Gadjah Mada University Press).

Anwar, Syamsul, 2007, Hukum Perjanjian Syariah: Studi tentang Teori Akad dalam Fikih Muamalat, (Jakarta: PT. RajaGrafindo Persada).

Basyir, Ahmad Azhar, 2000, Asas-Asas Hukum Muamalat (Hukum Perdata Islam), (Yogyakarta: Penerbit UII Press).

Dahlan, Abdul Azis (ed.), 1996, Ensiklopedi Hukum Islam, Jilid 5, (Jakarta: Ichtiar Baru van Hoeve).

Departemen Pendidikan Nasional, 2002, Kamus Besar Bahasa Indonesia. (Jakarta: Balai Pustaka).

Dewi, Gemala, 2005, Hukum Perikatan Islam di Indonesia, (Jakarta: Ken- cana).

Djamil, Fathurrahman, 2001, "Hukum Perjanjian Syariah", dalam Kom- pilasi Hukum Perikatan oleh Mariam Darus Badzrulzaman (et. al.), (Bandung: Citra Aditya Bakti).

- $\quad$,2005, "Fikih Muamalah", dalam Taufik Abdullah

(ed.), Ensiklopedi Tematis Dunia Islam, Jilid III, (Jakarta: Ichtiar Baru van Hoeve).

Djuwaini, Dimyauddin, 2008, Pengantar Fiqh Muamalah, (Yogyakarta:

Pustaka Pelajar). 
Ghufron, Sofiniyah (editor), 2005, Cara Mudah Memahami Akadakad Syariah, (Jakarta: Renaisan).

Ibn Hibban, 1414/1993, Shahih Ibn Hibban, XI, 340, Hadis No. 4967. (Bairut: Mu'assasah ar-Raisalah).

Ibn Majah, t.th., Sunan Ibn Majah, II, 737, Hadis no 2185. (Bairut: Dar al-Fikr).

Ibn Qudamah, 1981, Al-Mugni, V. (Riyad: Maktabat al-Riyad alHaditha).

Rahman, Asjmuni A., 1975, Qaidah-Qaidah Fikih, (Jakarta: Bulan Bin- tang).

Sabiq, Sayyid, t.th., Fiqh Sunnah, III (t.d.).

Saeed, Abdullah, 2006, Islamic Banking and Interest: A Study of Riba' and Its Contemporary Interpretation, terjemahan oleh Arif Maftuhin, Menyoal Bank Syariah: Kritik atas Interpretasi Bunga Bank Kaum Neo-Revivalis, (Jakarta: Paramadina).

Siddiqi, Nejatullah, 1996, Partnership and Profit Sharing in Islamic Law, terjemahan oleh Fakhriyah Mumtihani, Kemitraan Usaha dan Bagi Hasil dalam Hukum Islam, (Yogyakarta: Dana Bhakti Wakaf).

Vogel, Frank E. dan Samuel L. Hayes, 2007, Islamic Law and Finance: Religion, Risk, and Return, terjemahan oleh M. Sobirin Asnawi, Siwi Purwandari dan Waluyati Handayani, Hukum Keuangan Islam: Konsep, Teori dan Praktik, (Bandung: Nusamedia).

Zahrah, Muhammad Abu, t.th., Ushul al-Fiqh, (t.t.: Dar al-Fikr al'Arabi).

Zuhaili, Wahbah, 1989, Al-Fiqh al-Islami wa Adillatuhu, Jilid IV, (Damaskus: Daar al Fikr, Damaskus). 